\title{
Assessment of Continuous Oil and Gas Resources in the Niobrara Interval of the Cody Shale, Bighorn Basin Province, Wyoming and Montana, 2019
}

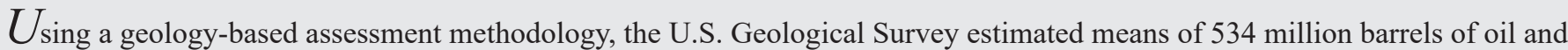 \\ 939 billion cubic feet of gas in the Niobrara interval of the Cody Shale in the Bighorn Basin Province, Wyoming and Montana.
}

\section{Introduction}

The U.S. Geological Survey (USGS) quantitatively assessed the potential for undiscovered, technically recoverable, continuous (unconventional) oil and gas resources in the Niobrara interval of the Cody Shale in the Bighorn Basin Province, Wyoming and Montana (fig. 1). In the Bighorn Basin, the Niobrara is represented by gray-to-black shale, calcareous shale, marl, and bentonite, with minor amounts of siltstone and sandstone in the lower part of the Upper Cretaceous Cody Shale (Finn, 2019). The strata were deposited in the Western Interior Seaway, which during much of the Cretaceous occupied an elongate north-south foreland basin that was bordered on the west by the tectonically active Cordilleran orogenic belt and on the east by the low-lying, stable North American craton (DeCelles, 2004). During the Laramide orogeny (Late Cretaceous through early Eocene), the central part of the foreland basin was fragmented into numerous smaller basins, such as the Bighorn Basin, that were flanked by rising basement-cored uplifts. These smaller basins subsided rapidly and were depocenters for the accumulation of thick lacustrine and continental sediments during latest Cretaceous through middle Miocene time (Love, 1988).

\section{Total Petroleum System and Assessment Units}

Finn and others (2010) defined the Cretaceous-Tertiary Composite Total Petroleum System (TPS) in the Bighorn Basin Province to include all Cretaceous, Paleocene, and lower Eocene strata. The Niobrara interval of the lower part of the Cody Shale is an element of the Cretaceous-Tertiary Composite TPS and includes both source and reservoir rocks. Source rocks occur in both the Niobrara and underlying Sage Breaks intervals and have total organic carbon contents of as much as 7 weight percent. The organic matter consists of Type II and mixed Type II/III kerogen with hydrogen index values of as much as 540 milligrams of hydrocarbon per gram of organic carbon (Finn, 2014). Potential reservoirs have carbonate contents of as much as 50 percent. The Niobrara interval is more organic-rich, oil-prone, and calcareous in the eastern and southeastern parts of the basin. Thermal maturity mapping, based on vitrinite reflectance $\left(\mathrm{R}_{\mathrm{o}}\right)$, shows that the Niobrara interval is thermally mature for oil generation ( $0.6-1.35$ percent $R_{0}$ ) along margins of the basin and mature for gas generation (greater than 1.35 percent $\mathrm{R}_{\mathrm{o}}$ ) in the deeper, more central parts of the basin (Finn and Pawlewicz, 2014). The Late Cretaceous through early Eocene Laramide orogeny and post-Laramide burial is considered to have thermally matured these organic-rich shales (Roberts and others, 2008).

The geologic model for the Niobrara continuous accumulations is for oil and gas to have been generated from oil-prone source rocks primarily during the Laramide orogeny and post-Laramide burial. Oil and gas were partially retained within the Niobrara interval following generation and migration into adjacent reservoirs. Two assessment units (AUs) were defined: (1) the Bighorn Niobrara Shale Oil AU encompasses

the area within the oil-generation window $\left(0.60-1.35\right.$ percent $\left.\mathrm{R}_{\mathrm{o}}\right)$, and (2) the Bighorn Niobrara Shale Gas AU includes the area where oil has been cracked to gas (greater than 1.35 percent $\mathrm{R}_{\mathrm{o}}$ ).

Assessment input data are summarized in table 1. Input data for estimated ultimate recoveries of wells are taken from the geologic analogs in the Sand Wash Basin part of the Southwestern Wyoming Province.

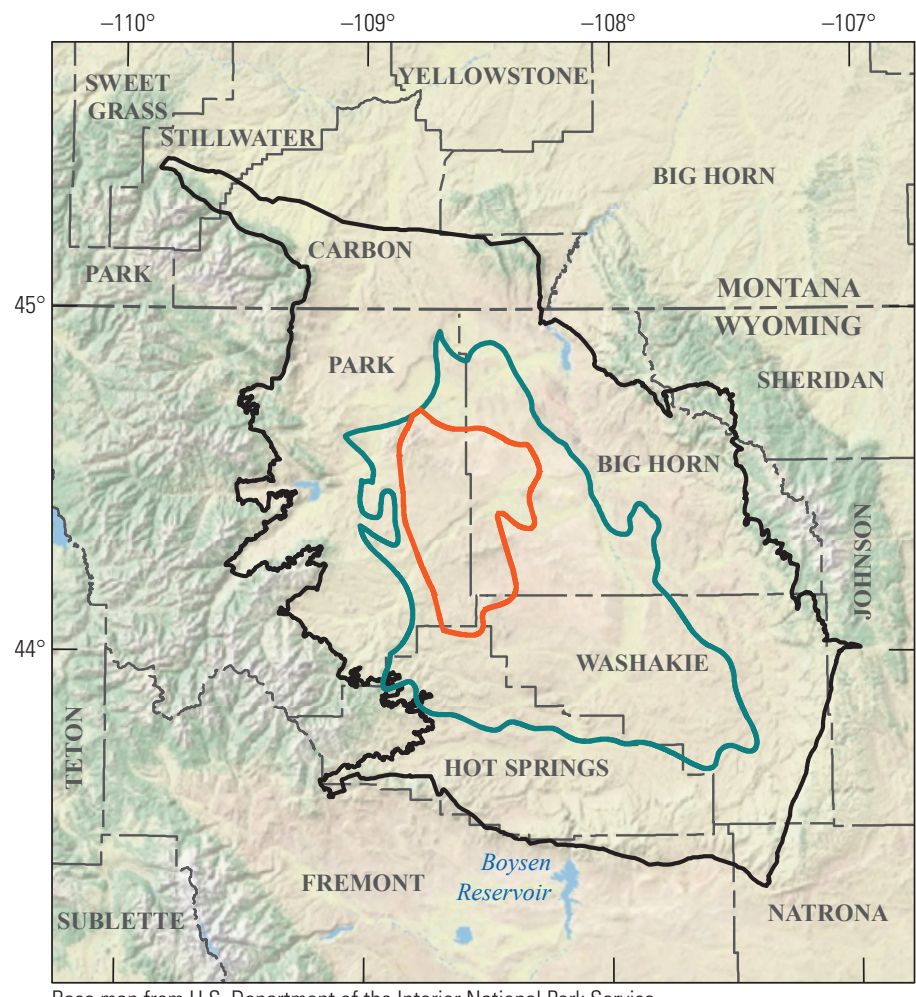

Base map from U.S. Department of the Interior National Park Service

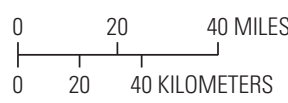

\section{EXPLANATION}

Bighorn Niobrara Shale Oil AU

Bighorn Niobrara Shale Gas AU

Bighorn Basin Province boundary

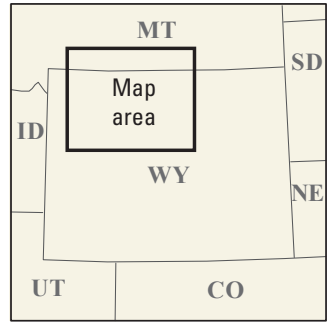

Figure 1. Map showing the continuous oil and gas assessment units (AUs) in the Niobrara interval of the Cody Shale, Bighorn Basin Province, Wyoming and Montana. Province boundary is from Finn and others (2010). 
Table 1. Key input data for the two continuous oil and gas assessment units in the Niobrara interval of the Cody Shale, Bighorn Basin Province, Wyoming and Montana.

[AU, assessment unit; \%, percent; EUR, estimated ultimate recovery per well; MMBO, million barrels of oil; BCFG, billion cubic feet of gas. Well drainage area, success ratio, and EUR are defined partly using U.S. shale-oil and shale-gas analogs. The average EUR input is the minimum, median, maximum, and calculated mean. Shading indicates not applicable]

\begin{tabular}{|c|c|c|c|c|c|c|c|c|}
\hline \multirow[b]{2}{*}{ Assessment input data-Continuous AUs } & \multicolumn{4}{|c|}{ Bighorn Niobrara Shale Oil AU } & \multicolumn{4}{|c|}{ Bighorn Niobrara Shale Gas AU } \\
\hline & Minimum & Mode & Maximum & $\begin{array}{c}\text { Calculated } \\
\text { mean }\end{array}$ & Minimum & Mode & Maximum & $\begin{array}{c}\text { Calculated } \\
\text { mean }\end{array}$ \\
\hline Potential production area of AU (acres) & 1,000 & 871,000 & $1,845,000$ & 905,667 & 1,000 & 120,000 & 536,000 & 219,000 \\
\hline Average drainage area of wells (acres) & 40 & 120 & 200 & 120 & 80 & 120 & 180 & 126.7 \\
\hline Success ratio $(\%)$ & 10 & 50 & 90 & 50 & 10 & 50 & 90 & 50 \\
\hline Average EUR (MMBO, oil; BCFG, gas) & 0.06 & 0.13 & 0.2 & 0.132 & 0.1 & 0.5 & 1.0 & 0.519 \\
\hline AU probability & 1.0 & & & & 0.9 & & & \\
\hline
\end{tabular}

\section{Undiscovered Resources Summary}

The USGS quantitatively assessed continuous oil and gas resources in two assessment units (table 2) in the Niobrara interval of the Cody Shale in the Bighorn Basin Province, Wyoming and Montana. For undiscovered, technically recoverable continuous oil and gas resources, the estimated mean totals are 534 million barrels of oil (MMBO) with an F95-F5 fractile range from 119 to 1,174 MMBO, 939 billion cubic feet of gas (BCFG) with an F95-F5 fractile range from 112 to 2,268 BCFG, and 32 million barrels of natural gas liquids (MMBNGL) with an F95-F5 fractile range from 6 to 77 MMBNGL.

Table 2. Results for two continuous assessment units in the Niobrara interval of the Cody Shale, Bighorn Basin Province, Wyoming and Montana.

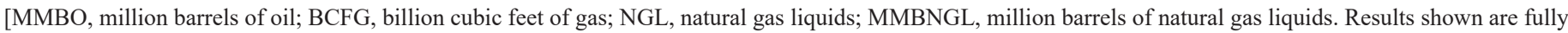

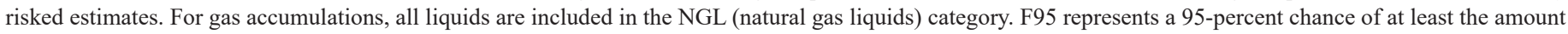
tabulated; other fractiles are defined similarly. Fractiles are additive under the assumption of perfect positive correlation. Shading indicates not applicable]

\begin{tabular}{|c|c|c|c|c|c|c|c|c|c|c|c|c|c|c|}
\hline \multirow{3}{*}{$\begin{array}{l}\text { Total petroleum system and } \\
\text { assessment units (AUs) }\end{array}$} & \multirow{3}{*}{$\underset{\text { probability }}{\text { AU }}$} & \multirow{3}{*}{$\begin{array}{l}\text { Accumula- } \\
\text { tion type }\end{array}$} & \multicolumn{12}{|c|}{ Total undiscovered resources } \\
\hline & & & \multicolumn{4}{|c|}{ Oil (MMBO) } & \multicolumn{4}{|c|}{ Gas (BCFG) } & \multicolumn{4}{|c|}{ NGL (MMBNGL) } \\
\hline & & & F95 & F50 & $\mathbf{F 5}$ & Mean & F95 & F50 & F5 & Mean & F95 & $\mathbf{F 5 0}$ & F5 & Mean \\
\hline \multicolumn{15}{|c|}{ Cretaceous-Tertiary Composite Total Petroleum System } \\
\hline Bighorn Niobrara Shale Oil AU & 1.0 & Oil & 119 & 466 & 1,174 & 534 & 112 & 456 & 1,228 & 534 & 6 & 27 & 76 & 32 \\
\hline Bighorn Niobrara Shale Gas AU & 0.9 & Gas & & & & & 0 & 337 & 1,040 & 405 & 0 & 0 & 1 & 0 \\
\hline $\begin{array}{l}\text { Total undiscovered continuous } \\
\text { resources }\end{array}$ & & & 119 & 466 & 1,174 & 534 & 112 & 793 & 2,268 & 939 & 6 & 27 & 77 & 32 \\
\hline
\end{tabular}

\section{References Cited}

DeCelles, P.G., 2004, Late Jurassic to Eocene evolution of the Cordilleran thrust belt and foreland basin system, western U.S.A.: American Journal of Science, v. 304, no. 2, p. 105-168.

Finn, T.M., 2014, Lower Cody Shale (Niobrara equivalent) in the Bighorn Basin, Wyoming and Montana-Thickness, distribution, and source rock potential: U.S. Geological Survey Scientific Investigations Report 2013-5138, 32 p.

Finn, T.M., 2019, Stratigraphic cross sections of the Niobrara interval of the Upper Cretaceous Cody Shale in the Bighorn Basin, Wyoming and Montana: U.S. Geological Survey Scientific Investigations Map 3422, pamphlet 19 p., 1 sheet [cross section], accessed February 2, 2019, at https://doi.org/10.3133/sim3422.

Finn, T.M., Kirschbaum, M.A., Roberts, S.B., Condon, S.M., Roberts, L.N.R., and Johnson, R.C., 2010, Cretaceous-Tertiary Composite Total Petroleum System (503402), Bighorn Basin, Wyoming and Montana, chap. 3 of U.S. Geological Survey Bighorn Basin Province Assessment Team, Petroleum systems and geologic assessment of oil and gas resources in the Bighorn Basin Province, Wyoming and Montana: U.S. Geological Survey Digital Data Series DDS-69-V, 157 p., CD-ROM.

Finn, T.M., and Pawlewicz, M.J., 2014, Maps showing thermal maturity of Upper Cretaceous marine shales in the Bighorn Basin, Wyoming and Montana: U.S. Geological Survey Scientific Investigations Map 3285, 14 p., 3 sheets, scale 1:500,000, accessed February 2, 2018, at https://doi.org/10.3133/sim3285.

Love, D.J., 1988, Geology of the Bighorn Basin, central Wyoming, in Sloss, L.L., ed., Sedimentary cover-North American craton-U.S.: The Geological Society of America, The Geology of North America, v. D-2, p. 201-204.

Roberts, L.N.R., Finn, T.M., Lewan, M.D., and Kirschbaum, M.A., 2008, Burial history, thermal maturity, and oil and gas generation history of source rocks in the Bighorn Basin, Wyoming and Montana: U.S. Geological Survey Scientific Investigations Report 2008-5037, 28 p.

\section{For More Information}

Assessment results are also available at the USGS Energy Resources Program website at https://energy.usgs.gov.

\section{Niobrara Assessment Team}

Thomas M. Finn, Christopher J. Schenk, Tracey J. Mercier, Marilyn E. Tennyson, Phuong A. Le, Michael E. Brownfield, Kristen R. Marra, Heidi M. Leathers-Miller, Ronald M. Drake II, Cheryl A. Woodall, Janet K. Pitman, Geoffrey S. Ellis, and Scott A. Kinney 